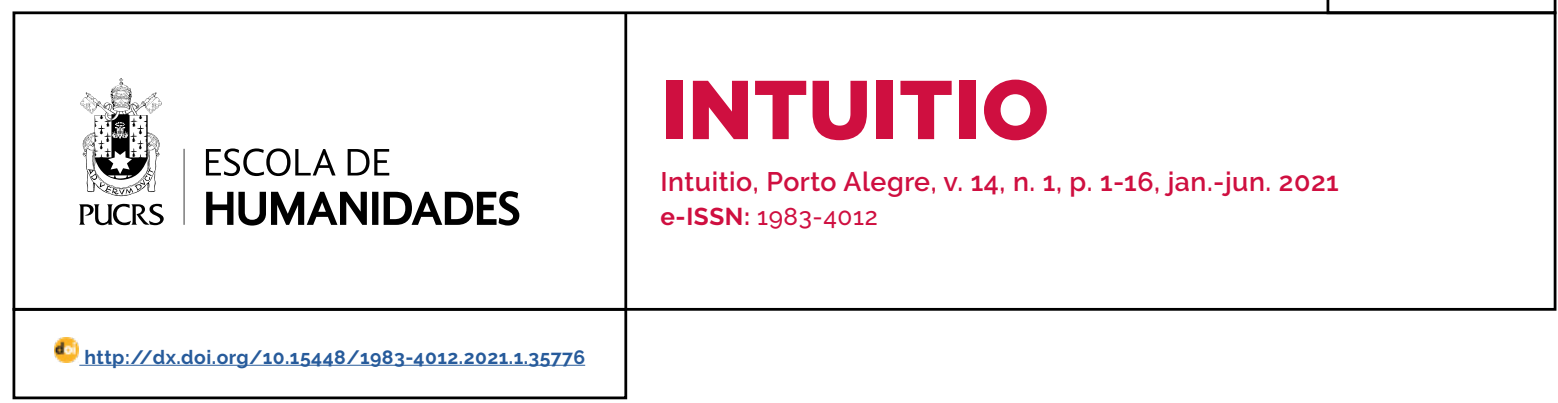

SEÇÃO: ARTIGO

\title{
Linguagem, convenção e conhecimento no Crátilo de Platão
}

\author{
Language, convention and knowledge in Plato's Cratylus
}

Cássio Mercier Ramos ${ }^{1}$ orcid.org/0000-0002-6251-4037 cassiomr123@gmail.com

Recebido em: 23/09/2019 Aprovado em: 04/05/2021. Publicado em: 02/09/2021.

\section{(c) (i)}

Artigo está licenciado sob forma de uma licença Creative Commons Atribuição 4.0 Internacional.
Resumo: O Crátilo é bastante enigmático quanto à forma com que encerra sua discussão sobre a justificação dos nomes, uma vez que planta a pergunta de como proceder ao conhecimento das coisas elas mesmas. Sendo assim, o desvelamento e clarificação da posição platônica contida no diálogo não poderiam deixar de ser assunto de muitas disputas e estudos. Este artigo tem por objetivo contrapor-se particularmente à visão de que Sócrates, ao final da obra, tome partido do convencionalismo com relação aos nomes, algo que é argumentado por Ademollo em seu importante comentário ao diálogo. Para tanto, faremos uma pequena análise das posições naturalista e convencionalista contida na discussão entre Hermógenes e Crátilo, para que, depois, sejamos conduzidos a uma reinterpretação daquilo que aqui apelidamos de "via socrática" levando em conta os vários elementos textuais presentes.

Palavra-chave: Platão. Crátilo. Linguagem. Convencionalismo.

Abstract: The Cratylus is quite puzzling as to how it ends its discussion of the justification of names, asking the question of how to know things in themselves. Thus, the unveiling and clarification of the Platonic position contained in the dialogue could not but be the subject of many disputes and studies. This article is intended in particular to contradict the view that Socrates, at the end of the work, adopts the conventionalist position of names, something that is argued by Ademollo in his important commentary on dialogue. To this end, we will make a short analysis of the naturalistic and conventionalist positions contained in the discussion between Hermogenes and Cratylus, so that, later, we will be led to a reinterpretation of what we call here the "socratic way", taking into account the various textual elements that are present.

Keywords: Plato. Cratylus. Language. Conventionalism.

\section{Introdução}

O diálogo Crátilo inicia-se de forma abrupta com um convite para que Sócrates tome parte em uma disputa que já vinha ocorrendo anteriormente e que dizia respeito à natureza dos nomes. Os personagens dessa disputa são Hermógenes e Crátilo. O primeiro, segundo Diógenes Laércio, teria sido discipulo de Parmênides, o mesmo que, certa volta, afirmara que "por isso tudo será nome quanto os mortais estatuiram, convictos de ser verdade", 3 evidenciando sua visão de que os nomes se opunham ao "verdadeiro ser", o que inspira o convencionalismo do personagem do diálogo. Crátilo, em oposição, é um proponente fervoroso da filosofia de Heráclito que propunha haver na linguagem uma 
expressão da "harmonia dos opostos". Posição que já no tempo de Platão havia se desfigurado em um esforço por parte de seus discipulos em justificar, por via etimológica, a famosa doutrina do eterno fluxo. ${ }^{3}$ Por esse motivo suas convicções o encaminhavam para uma posição que dependia de uma compreensão naturalista.

Torna-se agora claro que por detrás do drama que Platão elabora na criação do contexto dialógico existe a clássica oposição entre Parmênides e Heráclito do ser-uno e do fluxo; não por acaso a mesma que se observa posteriormente no Sofista. Esse é um primeiro indicio implícito de que o tema abordado, por mais que aparentemente diga respeito somente à correção dos nomes, inevitavelmente enveredará por um caminho ontológico. Isto é, já se pode desconfiar que a justificação final da questão dos nomes tem a ver com algum tema da metafísica platônica. Contudo, antes que se possa entender essa justificação final, será necessário compreender a disputa inicial entre Crátilo e Hermógenes e o porquê dessas duas posições serem insuficientes para dar conta da possibilidade do conhecimento racional. Com efeito, Platão percebe e pretende apontar de forma bastante irônica, como é de costume, que por debaixo dessa aparente polêmica com que se abre o diálogo está escondida uma unidade de resultado: a negação da Verdade.

Em um primeiro momento, a discussão se dá exclusivamente entre Hermógenes e Sócrates até o ponto em que a tese desse primeiro é aparentemente refutada e a de Crátilo endossada. O que é seguido por uma longa consideração etimológica, onde a perspectiva naturalista começa a ser restringida. Apenas ao final do diálogo é que Crátilo torna-se o interlocutor principal de Sócrates, no momento em que a refutação de sua tese é completada e prossegue em sentido ascendente para um vislumbre do cerne da filosofia platônica. Com efeito, o Crátilo é o primeiro diálogo em que Platão afirma com alguma clareza a realidade das ideias como um fundamento para o conhecimento, ainda que, conforme veremos, não as postule explicitamente como separadas da realidade material. ${ }^{4}$ Nesse momento, a via ontológica, que já havia sido anunciada acima, é finalmente tomada de forma explícita. A posição tomada por Sócrates, porém, quanto à justificação dos nomes não se apresenta com clareza, tendo sido interpretada diferentemente por muitos comentadores. Isso, contudo, representa um problema para a interpretação da questão final do diálogo sobre a possibilidade de se conhecer as coisas por elas mesmas (439b). Buscaremos esclarecer esse ponto de contenção do diálogo e, para tal, começaremos com a explicitação do convencionalismo e naturalismo para que deles derivemos os elementos para a compreensão da solução socrática.

\section{Hermógenes e o convencionalismo}

Não obstante ter sido descrito como um homem pobre por Xenofonte 5 (e mesmo por Platão em 384C), Hermógenes pertence a uma das mais poderosas familias atenienses de que se tem notícia. ${ }^{6}$ Filho de Hipônico, um homem extremamente rico que serviu como comandante militar em incursões feitas no território beócio em 426 a.C., Hermógenes, ao que tudo indica, era filho bastardo. Por isso, não recebeu parte na fortuna de seu pai, ao contrário de seu meio irmão Cálias, famoso patrono de sofistas. Xenofonte ${ }^{7}$ também o descreve como pertencendo ao círculo socrático, ainda que, tal como constatado acima, a Hermógenes tenha sido atribuído ser partidário da filosofia de Parmênides. Atribuição que explica sua posição convencionalista quanto à origem e correção dos nomes, tal qual se constata por suas falas no diálogo.

Hermógenes: Sócrates, para mim, após ter discutido várias vezes sobre isso com muitos outros, não consigo ser persuadido de que haja uma outra correção para um nome além

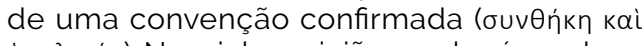
ònoגovía). Na minha opinião, se alguém coloca

\footnotetext{
FRIEDLÄNDER, P. Plato: The Dialogues, First Period. Translation by Hans Meyerhoff. New York: Pantheon Books, 1964. v. 2.

VAZ, H. C. de L. Contemplação e dialética nos diálogos platônicos. São Paulo: Edições Loyola, 2012. p. 63-64.

XENOFONTE. Ditos e Feitos Memoráveis de Sócrates. São Paulo: Editora Nova Cultura, 1999. p. 161.

ADEMOLLO, F. The Cratylus of Plato: a commentary. Cambridge: Cambridge University Press, 2011. p. 18-19.

XENOFONTE. op. cit., p. 85-98
} 
um nome numa coisa, este está correto (ötı ăv

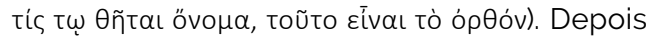
disso, se for mudado para um outro, e ninguém mais chamar pelo primeiro, o novo não vai ser menos correto que o anterior. ${ }^{8}$

Aquilo que se pode depreender imediatamente desse convencionalismo defendido por Hermógenes, observado a partir da citação acima, é que a correção dos nomes está colocada inteiramente na dependência de uma "convenção confirmada"

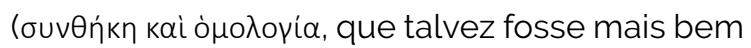
traduzido por "convenção e concordância"). Esse aspecto final de confirmação ou concordância da convenção estabelecida revela uma aparente relação temporal entre esses dois termos, que pode ser entendida da forma que segue: em primeiro lugar há uma "øuvӨńkn", que significa tanto "convenção" quanto "composição" (o ver-

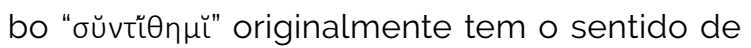
"ajuntar"); já em um segundo momento há uma "ò correspondência (ò $\mu$ ćc) discursiva ou racional (入óyoc), mas que aqui foi traduzido no sentido de uma "confirmação". Ora, uma vez que se façam essas ressalvas, fica patente que apenas esse último termo implica de forma necessária uma relação com um outro individuo. Com efeito, conquanto a composição possa ser solitária, a confirmação discursiva depende de pelo menos mais um agente que desempenhe o papel de confirmador. $^{9}$ É aí que entra a diferença, apresentada logo na sequência do diálogo, entre os "nomes públicos" e os "nomes privados", uma vez que os primeiros receberam a confirmação, mas esses últimos ainda não.

Ademais, tal como nota Ademollo ${ }^{10} \mathrm{em} \mathrm{seu}$ comentário, o uso do pronome "tíc" (traduzido por "alguém") na fala de Hermógenes claramente traz um enfoque adicional na questão do falante individual. Isto é, reforça a ideia de que a nomenclatura parte da decisão arbitrária de um sujeito qualquer. Salta aos olhos de imediato a relação de proximidade que essa tese apresenta com a famosa máxima de Protágoras de que "o homem é a medida de todas as coisas". ${ }^{11}$ De fato, Hermógenes, tal como nota Sócrates na sequência, parece caminhar justamente no sentido dessa conclusão, que acabará servindo como a base para a refutação da tese convencionalista. Essa relação com Protágoras fica ainda mais patente uma vez que se perceba que, não havendo nada no nome que seja inerente à natureza da coisa, a única diferença de correção que pode haver entre um nome e outro é de cunho puramente quantitativo. Isto é, quantos falantes de uma determinada língua aceitam usar um determinado nome em lugar de outro. Fator que remete a uma ideia de imposição. Logo, a correção dos nomes para Hermógenes só pode dizer respeito a como um falante consegue que sua nomenclatura e seu discurso sejam adotados pelos demais, seja por via do convencimento, do hábito ou da força. Essa compreensão encaminha à diferenciação, no momento seguinte, de dois niveis de nomenclatura. Os nomes privados e os nomes públicos. Já foi apresentada anteriormente a característica distintiva entre eles (isto é, a confirmação social), mas se retirado este aspecto puramente quantitativo não há qualquer coisa que justifique um em oposição ao outro. Com efeito, seguindo essa linha de raciocinio se está fadado a cair em um indiferentismo que, tomado de forma absoluta, faz da lingua um sistema fechado e, portanto, apenas capaz de se referir a si mesma. ${ }^{12}$ Contudo, se a língua não é capaz de referenciar a realidade das coisas externas, então não é possivvel haver adequação entre realidade e discurso, impossibilitando que exista algo como dizer verdade ou

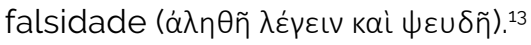

De fato, o diálogo Teeteto concede, por outra via, uma mesma perspectiva acerca dessa questão. Na

\footnotetext{
PLATÃo. Crátilo. Tradução de Celso de Oliveira Vieira. 1 ed. São Paulo: Paulus, 2014. 384C-e. p. 24.

Essa relação entre nomeador e confirmador foi tomada por alguns comentadores como indicativa de uma contradição no discurso de Hermógenes, o que os levou a postular que a fala desse personagem contém duas versões da mesma tese: uma radical e uma moderada. Contudo, não se crê haver evidências suficientes para sustentar essa tese.

10 ADEMOLLO, op. cit., p. 40.

1 DIELS; KRANZ, op. cit., 8ob1; FRIEDLÄNDER, op. cit., p. 198

12 FRIEDLÄNDER, op. cit, p. 196.

13 PLATÃo. Crátilo. Tradução de Celso de Oliveira Vieira. 1 ed. São Paulo: Editora Paulus, 2014. 385b, p. 25.
} 
segunda tentativa do jovem personagem Teeteto de formular uma resposta à pergunta "тí бо ठокє

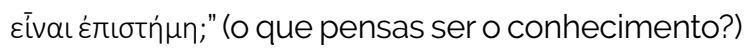
${ }^{14}$, é apresentada a opinião de que conhecimento seria percepção sensorial. ${ }^{15}$ Algo que é imediatamente remetido por Sócrates como sendo também a posição de Protágoras. Seguindo por essa linha de pensamento chega-se à inevitável conclusão de que o conhecimento é relativo a cada individuo particular e, portanto, que o homem é a medida de todas as coisas. Porém Sócrates nota de forma bastante acertada que essa posição tem a tendência de se espalhar para além do âmbito do puro conhecimento, principalmente na direção da discussão acerca da justiça; fazendo com que seja considerada justa qualquer lei promulgada por uma cidade, pois é a autoridade da cidade que impõe sua legislação e, nesse sentido, a justifica. Não havendo, assim, justificação da lei para além da imposição, exatamente como para Hermógenes não há correção no nome para além da sua vaga ideia de "confirmação", o problema apresentado é o mesmo nos dois casos. A solução socrática vem da observação de que essa forma de pensar acaba por tornar-se absurda, uma vez que se considere a lei sob o aspecto de sua utilidade, visto que não basta uma determinação da cidade para tornar algo útil (ou bom), mas a coisa ela mesma tem de o ser. ${ }^{16}$ Assim, chega-se a uma constatação reveladora: uma vez que não basta a imposição para tornar uma lei útil (sendo necessário uma confirmação através da coisa mesma acerca da qual se legisla), o legislador "não deve se limitar ao nome, mas a coisa nomeada tem que ser objeto de sua atenção".17

Partindo dessas observações, já estamos capacitados para compreender a refutação que será feita do convencionalismo. Algo que no diálogo se passa de forma bastante sutil. O primeiro movimento socrático é estabelecer a existência do discurso verdadeiro e do falso, algo que Hermógenes concede com facilidade. Nesse ponto somos obrigados a concordar com Friedländer ${ }^{18}$ quando diz que Platão não fez de Hermógenes um pensador consistente, porque já nessa primeira concessão a sua opinião acerca dos nomes está fadada à refutação, dado que, conforme se notou acima, as conclusões que se seguem a um convencionalismo absoluto são incompativeis com a existência de verdade e da falsidade. Sócrates então pergunta se pode uma frase ser verdadeira não o sendo também as suas partes. Uma vez estabelecida a necessidade de que as partes sejam verdadeiras, segue-se logicamente que deve haver nomes verdadeiros e falsos. Alguns comentadores ${ }^{19}$ condenaram essa linha argumentativa acusando Sócrates de cometer a falácia da divisão, isto é, atribuir à parte uma propriedade do todo. Contudo, é possivel evitar esta conclusão ${ }^{20}$ uma vez que se perceba que Platão trata, ao menos alguns nomes, como sendo predicados, tal como indicado em Crátilo 399b e 431b. Uma prova adicional disso, tal como indica Bagwell, ${ }^{21}$ é que muitos dos nomes explicados na parte etimológica do diálogo são apresentados como contrações de afirmações ou frases inteiras. Seja como for, o próprio contexto do argumento impede que a falácia seja imputada a Platão, uma vez que é Hermógenes, e não Sócrates, que insiste na atribuição de valor de verdade para os nomes, mesmo quando, por três vezes, the é oferecida a oportunidades de rejeitar essa afirmação em 385c.

No movimento seguinte, Sócrates consegue a concessão da existência de uma "estabilidade" que seria própria a cada coisa independentemente do sujeito, partindo-se da admissão de que existem "homens maus" (386a-b). Seguindo essa

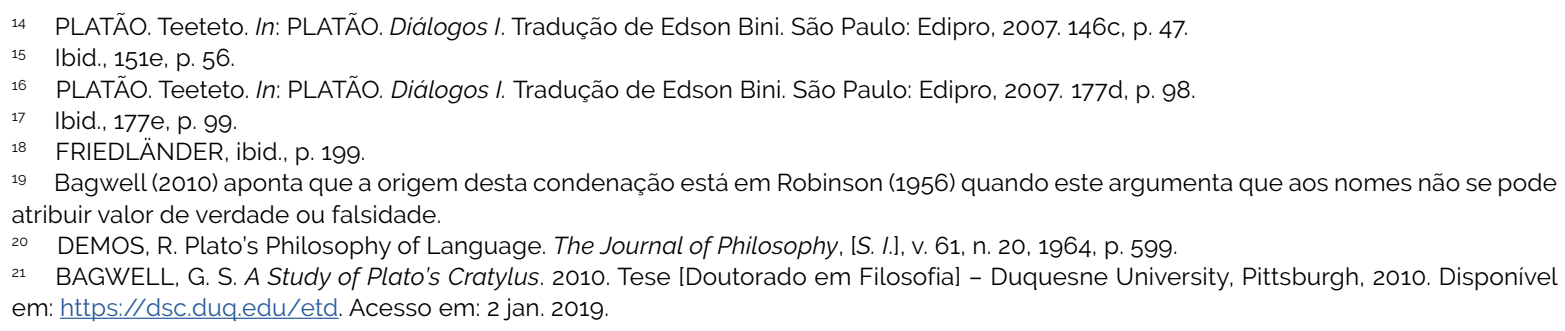


mesma linha, o filósofo aproveita para assegurar também a existência de "homens sensatos e insensatos", passando, portanto, da via ética para a epistemológica, ${ }^{22}$ e objetando, desse modo, tanto a posição de Protágoras quanto a de Eutidemo. Estes dois sofistas estão ligados a uma perspectiva relativista, porém chegam a ela por vias diversas. Já notamos como a tese de Protágoras é insuficiente e como termina por negar a justiça e mesmo a sabedoria. Resta, portanto, tratar do que dizia Eutidemo, cuja tese, segundo Platão, postulava que "tudo existe para todos do mesmo jeito sempre, ao mesmo tempo e para sempre".23 Ademollo $^{24}$ nota duas possiveis interpretações que se fizeram acerca dessa posição: alguns sustentaram, como Proclo, que o "tudo" ( $\pi \alpha ́ v \tau \alpha)$ significava "todas as propriedades", querendo dizer, portanto, que qualquer propriedade pode ser atribuida a qualquer coisa; outros entenderam que "tudo" era apenas uma expressão geral, pondo o enfoque na expressão "para todos" ( $\pi \tilde{a} \sigma \iota)$, asseverando ser essa posição um contraste coletivo da máxima de Protágoras, uma vez que este pensava serem as coisas relativas a cada um. Qualquer que seja a interpretação realizada o resultado será invariavelmente a queda em um relativismo e a negação, ou impossibilidade, de dizer verdade. Donde Sócrates conclui a absoluta necessidade de que haja a supracitada estabilidade própria de cada coisa, e que esta não dependa de forma alguma do observador. O argumento prossegue no sentido de passar essa mesma qualidade estável dos objetos para o âmbito do agir e das ações.

Sócrates: Portanto, também as ações atuam conforme sua própria natureza e não segundo a nossa opinião. Se nos propusermos a cortar algo que existe, por exemplo, convém cortarmos cada qual como quisermos e com aquilo que quisermos ou convém querermos cortar segundo a natureza inerente ao cortar e ao ser cortado? Desse modo, agindo corretamente, cortaremos algo de pleno para nós enquanto que, errando, contra a natureza, sequer agiremos. ${ }^{25}$
Nesse ponto a arbitrariedade da imposição enquanto definidora do modelo ético, tal qual pregada pelos relativistas, é integralmente substituída pela noção socrática de um pragmatismo que, ao afirmar uma natureza (oú бía) própria das

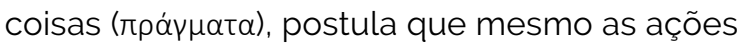
devem ser entendidas no sentido de serem detentoras de uma natureza própria; algo que deve servir como modelo regulador da ação humana para além de qualquer busca de uma simples gratificação pelo prazer. ${ }^{26} \mathrm{O}$ exemplo dado acima na fala de Sócrates é o da ação de cortar, onde se veem claramente os dois modelos de referência: a própria ação e a coisa cortada. De fato, para cortar bem não é necessário apenas um conhecimento genérico do cortar (embora esse seja necessário), mas requer-se também um conhecimento especíico do objeto a ser cortado naquelas características que têm relevância relativamente à ação a ser perpetrada. O importante para o seguimento do diálogo é a aplicação desse esquema para a ação de nomear. Essa também envolve uma natureza própria de seu agir e um objeto de ação que é a própria coisa nomeada. Aqui, finalmente, tem vez a classificação dos nomes como instrumentos do nomear e do distinguir (388a-d). Conclui-se, portanto, que a justificação dos nomes não pode ser atribuída a uma mera imposição convencional, mas deve referir-se obrigatoriamente à coisa nomeada. Destarte, o convencionalismo de Hermógenes já se apresenta refutado e o caminho percorrido até então no diálogo parece apontar decididamente na direção de um naturalismo dos nomes.

É precisamente sobre esse argumento e o seu desenvolvimento que trataremos a seguir, porém ainda resta um ponto a ser analisado aqui. Primeiro, a compreensão do nome como um instrumento leva à questão de qual função precisamente the deva ser atribuída. Essa é definida como a de informar e distinguir a existência, algo que defi-

\footnotetext{
22 Essa passagem de ética para epistemologia é absolutamente essencial na filosofia socrática e platônica, uma vez que os dois atribuíam à causa dos vícios uma falta de sabedoria. Vide o diálogo Mênon 86c-89c e Fédon 68c-69c.

23 PLATÃO. Crátilo. Tradução de Celso de Oliveira Vieira. 1. ed. São Paulo: Editora Paulus, 2014. 386d, p. 27.

24 ADEMOLLO, op. cit., p. 85.

25 PLATÃo. Crátilo. Tradução de Celso de Oliveira Vieira. 1. ed. São Paulo: Editora Paulus, 2014. 387a, p. 28.

26 FRIEDLÄNDER, op. cit. p. 200
} 
nitivamente corrobora a tese de Sedley sobre a teleologia da linguagem em Platão, entendida como instrumento dialético, ${ }^{27}$ uma vez que o movimento dialético é passivel de ser compreendido como buscando esta distinção da existência em seus vários niveis. Com efeito, Sócrates introduz

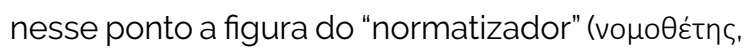
às vezes traduzido como "legislador"), descrito

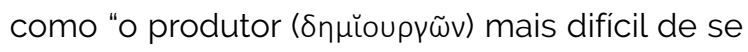
gerar entre os humanos".28 Já no comentário de Proclo esse normatizador é associado ao Demiurgo que viria a emergir explicitamente no Timeu. ${ }^{29}$ Sua tarefa, tal como apresentada no diálogo em discussão, é a de gerar os nomes a partir dos modelos estáveis das coisas nomeadas, afigurando-se como um verdadeiro óvopatoupyós. Todavia, Proclo vai ainda mais longe ao notar que no Timeu chega-se a afirmar (em 35c) que o Demiurgo é quem denomina um dos movimentos de rotação da alma do mundo de "idêntico", e o outro de "diferente", concluindo assim que a função desses dois produtores não é apenas análoga, mas que o Demiurgo é de fato o primeiro normatizador. ${ }^{30}$ Goldschmidt chegou a propor que Platão realmente tenha tomado emprestado dos pitagóricos essa noção de um "nomeador divino", mas concordamos com Ademollo ${ }^{31}$ que essa posição é bastante dúbia. Por ora, basta a observação de que, mais uma vez, Platão indica de forma sutil o verdadeiro tema que se esconde por debaixo da discussão a respeito da correção dos nomes: as ideias eternas. Afinal, são elas que devem servir de verdadeiro modelo para que o normatizador cunhe os nomes. Porém antes que se possa aportar definitivamente nesta compreensão será necessário descartar mais uma posição comum no pensamento grego da época com relação a este assunto, nomeadamente o naturalismo.

\section{Crátilo e o naturalismo}

Ateniense e supostamente filho de Smicron, a identidade por trás do personagem Crátilo revelou-se um tanto problemática aos comentadores e acadêmicos que se prestaram a investigá-la. ${ }^{32}$ As poucas fontes que temos são os relatos de Platão e de Aristóteles que, uma vez analisados, revelam um quadro bastante interessante. Do diálogo platônico se pode depreender a sua filiação e nacionalidade (429e), o fato de ser notavelmente mais jovem do que Sócrates (440d) e de estar em vias de se tornar um seguidor dos ensinamentos de Heráclito (440d-e). Da fonte aristotélica, contida na Metafísica, ${ }^{33}$ depreendemos que Platão, ainda jovem e antes de tornar-se discipulo de Sócrates, tomou conhecimento de Crátilo e das doutrinas de Heráclito que este já professava totalmente. Naquela mesma obra também nos é indicado que, no final de sua vida, as posições de Crátilo tornaram-se tão extremadas que o levaram a abandonar a fala por completo, julgando ser o silêncio total a atitude correta face ao fluxo eterno e absoluto de todas as coisas, restringindo-se, quando necessário, apenas a apontar as coisas com o dedo. Esse extremismo averigua-se também em sua crítica tardia ao ensinamento de Heráclito sobre ser impossivel adentrar duas vezes o mesmo rio, posto que considerasse ser impossível fazê-lo mesmo que uma só vez. ${ }^{34}$ Isso porque na própria duração do ato de entrar no rio, nem esse nem o individuo que atua perduram, visto que participam da constante mudança do todo, não havendo por onde dizer que sejam os mesmos.

Partindo desses testemunhos percebemos que o Crátilo se situa em um momento muito específico do desenvolvimento intelectual do personagem homônimo. De fato, como seria possivel não remeter sua tardia "renúncia da palavra" imediatamente ao tema do diálogo, isto é, a

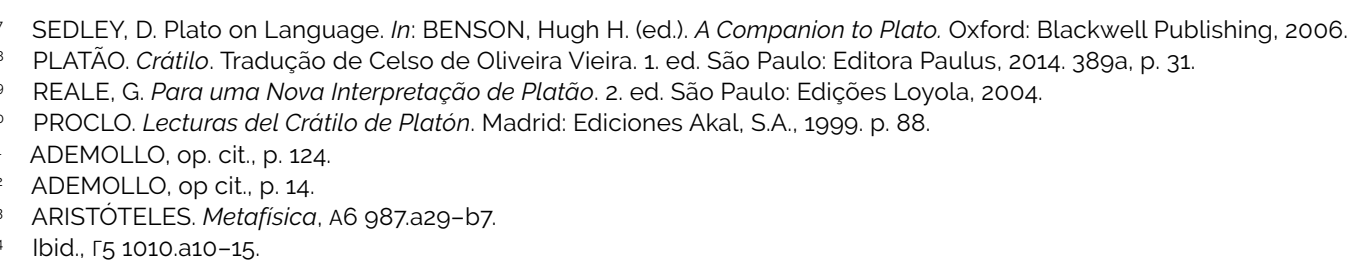


correção dos nomes? De fato, Sedley 35 interpreta o raciocínio que teria encaminhado Crátilo a esse extremismo de sua maturidade como sendo uma percepção de que o fluxo constante das coisas, para além de privar um homem da possibilidade de entrar em um mesmo rio, como vimos acima, priva-o do próprio ato de nomear, pois uma vez que tudo se altera não haveria mais a possibilidade de referenciar os objetos do mundo sem que, já ao final desse ato mesmo, esses tenham mudado. Assim, a única via que lhe restava, ainda segundo o mesmo comentador, era o mero recurso ao apontar das coisas com o dedo. Algo que, conforme nota Ademollo, ${ }^{36}$ não resolve o problema da impossibilidade do referir-se a um determinado objeto, mas que, de certa forma, burlava o problema da identidade ou justificação entre nome e coisa, que, tal como apontamos, é exatamente o mesmo tema que está sendo discutido no diálogo por Sócrates.

Até agora o argumento levado por Sócrates havia discernido a impossibilidade de que os nomes fossem totalmente convencionais. Com efeito, será necessário que haja algum elemento de relação com a natureza do objeto referenciado, mas a proporção desse elemento na composição do nome ainda é incerta. Será necessário, portanto, que consideremos os modos com os quais se pode dizer que algo é por natureza, a fim de que possamos distinguir os vários tipos de argumento que poderão emergir no diálogo e, assim, facilitar que venhamos a compreender a posição naturalista a ser utilizada por Crátilo em oposição àquela que terá o endosso final de Sócrates. Para tanto, recorramos ao comentário de Proclo, ${ }^{37}$ onde são indicados quatro possíveis modos de interpretar o "ser por natureza" de algo. Em primeiro lugar, algo é por natureza no mesmo sentido em que é por essência. Um exemplo disso seria dizer que o homem é, por natureza, um animal racional. O segundo modo é conforme as atividades ou potências de algo, por exemplo, o falar e o pensar são naturais ao homem. O terceiro modo diz respeito às imagens ou representações naturais de uma coisa. Por exemplo, a sombra e o reflexo de um homem lhe são naturais. Finalmente, o quarto modo de indicar a natureza de algo é segundo as suas imagens produzidas artificialmente. Por exemplo, a imagem esculpida de um homem por outro the é naturalmente assemelhada.

Se aplicarmos esse esquema ao raciocínio até então apresentado por Sócrates em sua discussão com Hermógenes, poderíamos ser tentados a classificar sua visão como participando do segundo modelo de compreensão do "ser por natureza", isto é, aquela que diz respeito às ações e potências. De fato, o nomear havia sido descrito em 387a como uma ação possuidora de uma natureza apropriada e não seria absurdo supor, portanto, que os nomes the seguissem nesta mesma naturalidade. Santo Tomás de Aquino em seu Comentário ao Sobre a Interpretação faz uma análise similar dese argumento (o qual ele conhecia apenas por via indireta), atribuindo a Platão o princípio de que "é necessário que uma faculdade natural tenha instrumentos naturais, porque a natureza não falha nas coisas necessárias". ${ }^{8}$ Assim, se o nomear é compreendido como uma ação natural ao homem e o nome como seu instrumento (388a), haveríamos de supor que os nomes têm de ser dispostos também segundo a natureza apropriada. Essa, porém, não nos parece a forma correta de entender o argumento proposto, uma vez que, apesar de ter sido realmente defendida por alguns filósofos como Epicuro, ${ }^{39}$ destoa da posição que Sócrates exprime acerca da formação dos nomes. Os instrumentos naturais do nomear de fato nos são dispostos por natureza, e esses são o pulmão e as cordas vocais. ${ }^{40}$ Seu produto natural é apenas a voz indefinida ( $\phi \omega v n ́)$, mas que ainda não foi

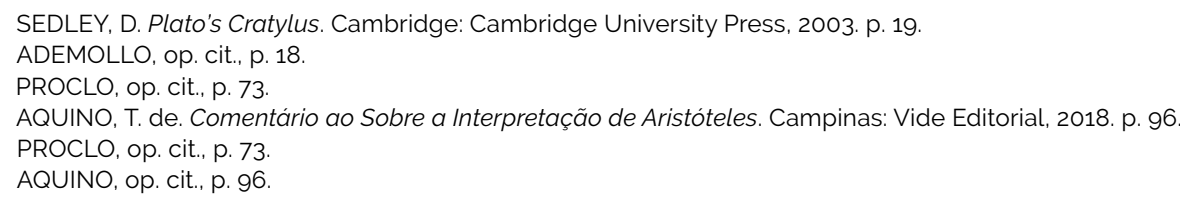


constituida no som significativo que pode ser propriamente chamado de nome. ${ }^{41}$ De fato, se o nome nos fosse disposto por natureza seguindo o modelo do argumento supracitado não seria possivel declarar o nomear como sendo uma técnica, e muito menos uma que necessitasse da ação do mais raro entre os artesãos: o normatizador (389a). Uma vez que tenhamos separado o nomear do mero balbuciar fica evidente que o elemento que distingue um do outro é a provisão no som de um conteúdo simbólico e significativo, que deve ser disposto em acordo com a arte, tal como aponta Sócrates abaixo.

Sócrates: Então, meu caro, o normatizador deve também ter a consciência de colocar uma natureza inerente a cada nome através dos sons e sílabas. E, caso almeje ser um perito na colocação de nomes, ele deve fazer e colocar todos os nomes olhando ( $\beta \lambda \varepsilon \dot{\pi}$ ovta $\pi \rho$ ós) para aquilo mesmo de que este é um nome. Além disso, não devemos sequer questionar por que cada normatizador não usa as mesmas sílabas já que tampouco todo ferreiro usa o mesmo ferro só porque está fazendo um mesmo instrumento. Ainda que seja num outro ferro, tudo vai ficar igual se ele aplicar uma mesma especificação. ${ }^{42}$

Fica claro, portanto, que a justificação natural dos nomes deverá ser compreendida segundo o terceiro ou o quarto modelo de Proclo, isto é, como uma imagem natural ou como uma artificial da coisa nomeada. Nesse sentido já estamos mais bem capacitados para averiguar a posição particular que toma Crátilo. Essa, porém, não será evidenciada de forma clara logo de início, mas passará por um longo preâmbulo etimológico, onde a questão do grau de naturalidade presente no nome será posta à prova por Sócrates. Os pontos que já são tomados como certos em 39od-e são: a) Crátilo está correto em admitir que os nomes sejam por natureza; b) nem todos podem ser produtores de nomes, tal como havia afirmado anteriormente Hermógenes; e c) apenas aqueles que olham para "o nome por natureza de cada ser" serão os verdadeiros produtores de nomes, na medida em que sigam o principio de "colocar sua

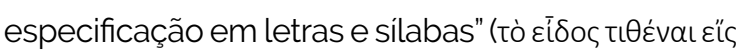

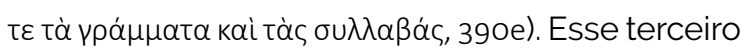
ponto, tal como evidenciado na citação acima, ${ }^{43}$ derruba a sugestão de Hermógenes em 385d-e de que a existência de várias línguas pudesse ser um argumento contra o naturalismo, dado que um normatizador pode usar silabas diferentes para encapsular a mesma forma ( $\varepsilon \bar{\delta} \delta \circ \varsigma)$. Isso, porém, traz à tona a necessidade de definir o que seja essa "forma" presente nos nomes.

A metáfora que é utilizada aqui diversas vezes

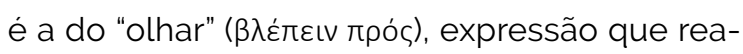
parecerá em outros diálogos ${ }^{44}$ sempre ligada, de algum modo, com a imagem do artesão ou pro-

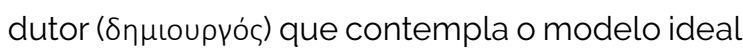
da coisa produzida. Nesse sentido, seria dificil não remeter esse ponto à teoria das ideias, tal como o faz Licata, ${ }^{45}$ e, de fato, os paralelos são claros, porém a forma do nome não deve ser entendida como sendo simplesmente uma referência à ideia da coisa a ser nomeada. Isso porque, seguindo o raciocinio apresentado anteriormente, o fator distintivo do nome é seu o significado, e Sócrates parece estar argumentando que esse deve, de algum modo, transparecer na própria organização do nome enquanto conjunto de sons e silabas. A ideia do nome é, portanto, como as ideias dos artefacta das quais tratou Reale,$^{46}$ descrevendo-as como ideias intermediárias geradas por ação da inteligência demiúrgica. Dessa concepção surge o elemento central da visão naturalista de Crátilo, e que acabará por gerar o ímpeto etimológico do diálogo. Até então, o argumento de Hermógenes, apesar de ser insuficiente, não era irreconciliável com as asserções socráticas, ${ }^{47}$ uma vez que pretendia tratar apenas da constituição material (isto é, sonora ou fonética) de um nome. Porém, tal como acertadamente nota Ademollo, ${ }^{48}$ quando

\footnotetext{
DEMOS, op. cit., p. 600.

PLATÃo. Crátilo. Tradução de Celso de Oliveira Vieira. 1. ed. São Paulo: Editora Paulus, 2014. 389d-e, p. 32.

Ibid., p. 32.

Como, por exemplo, na República em X, 596.b.

LICATA, G. Teoria dei nomi e teoria delle idee in Platone. Dialegesthai. Rivista telematica di filosofia, Roma, ano 3, 2002.

REALE, G. Para uma Nova Interpretação de Platão. 2. ed. São Paulo: Edições Loyola, 2004. p. 526.

ACKRILL, J. L. Language and Reality in Plato's Cratylus. In: Essays on Plato and Aristotle. Oxford: Oxford University Press, 1997. p. 44.

ADEMOLLO, op. cit., p. 135.
} 
Sócrates se refere a uma imposição da natureza nas sílabas (tal como vimos em 389d) há uma clara referência à tese de Crátilo apresentada logo no começo do diálogo em 383a. Aqui, já podemos ter como claro que a própria estrutura material do nome constituída de seus fonemas deve expressar a sua realidade simbólica. Em outras palavras, a estrutura do nome deve ser um reflexo natural de seu significado, e é justamente por isso que Proclo classifica a posição de Crátilo como pertencendo ao terceiro modo do "ser por natureza".49

Importante observar, quanto a esse ponto, que essa atitude racionalizante, encabeçada pelo personagem Crátilo, contém não apenas premissas questionáveis, mas também consequências inaceitáveis de um ponto de vista platônico. Em primeiro lugar, supõe que há uma fixidez no nome justamente em sua relação material ou fonética, capacitando que seja, para além de um instrumento de discernimento, tal como dizia Sócrates (388a), uma via de instrução confiável e certa sobre a natureza mesma da realidade. Assim, a tese se mostra imediatamente contraditória, na medida em que a visão de natureza que pretende estabelecer é justamente a da negação da fixidez (se bem que ainda entendida de forma parcial). Destarte, no momento em que Sócrates começa a explorar a posição de Homero sobre a correção dos nomes, vemos que a tese naturalista que está construindo faz depender tudo da etimologia do nome, e mais precisamente na suposição de que o étimo de um nome deve fornecer uma descrição da coisa referida. ${ }^{50}$ Por isso mesmo é que Crátilo tem de negar que um nome que não funcione nestes moldes, fornecendo a descrição que ele julgue adequada, possa ser sequer considerado como um nome, mas que deva ser entendido apenas como um "barulho de um movimento em vão" (429b-e). É esse pensamento que o levará à negação da possibilidade de dizer o falso, porque o ato de falar deverá estar sempre ajustado à natureza das coisas se verdadeiramente se constituir enquanto tal.

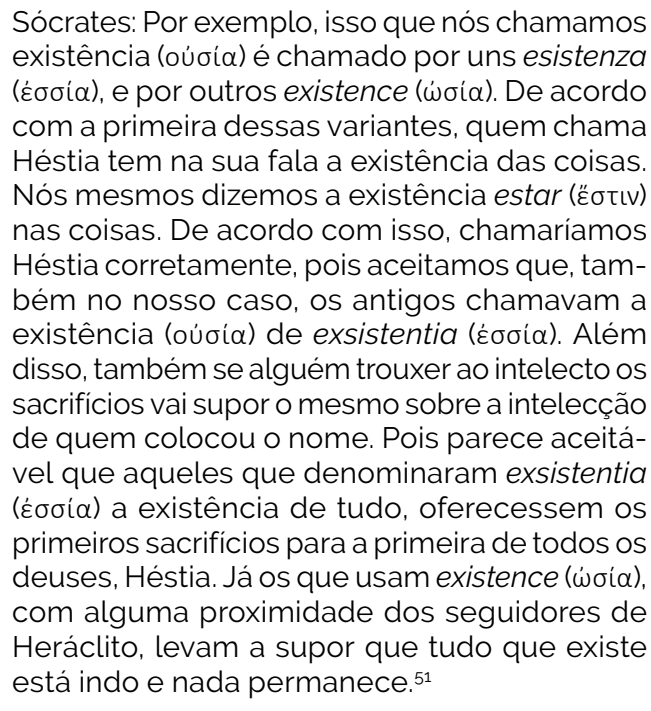

Nessa longa fala podemos ver um exemplo do uso das etimologias para confirmação ou justificação das teorias de Heráclito, ${ }^{52}$ visto que aproxima o ser ou a existência (oú бía) do movimento (ú日oũv). Sedley53 aponta, em seu comentário, que todas as variações apresentadas por Platão nos dialetos gregos servem também no sentido de refletir e enfatizar a confusão do verdadeiro ser e apontar a sua instabilidade e fluidez. Conclusões similares reaparecerão na análise que o filósofo fará de Reia e Cronos logo na sequência e, tal como nota Bagwell, ${ }^{54}$ constituem o tema fundamental dessa parte do diálogo. Tendo-se compreendido o escopo e a origem do impulso etimológico resta explicar mais detalhadamente o modo como os sons de um nome poderiam refletir sua natureza formal. Sócrates divide os nomes em dois, os primários e os derivados (422a-b), e a forma de organização e correção é diferente para cada um. Os primeiros analisados são os nomes derivados e a sua característica definitiva é serem compostos de nomes primá-

49 Conforme visto, aquele que diz respeito aos reflexos naturais de uma coisa, como sua sombra ou sua imagem refletida n'água. PRO-

CLO. Lecturas del Crátilo de Platón. Madrid: Ediciones Akal, 1999. p. 73.

$50 \quad$ ADEMOLLO, op. cit., p. 157.

51 PLATÃo. Crátilo. Tradução de Celso de Oliveira Vieira. 1 ed. São Paulo: Editora Paulus, 2014. 401c-e, p.49-49.

52 Aqui estamos em acordo com Sedley (2003) e Bagwell (2010).

53 SEDLEY, D. Plato's Cratylus. Cambridge: Cambridge University Press, 2003. p. 102-103.

54 BAGWELL, op. cit., p. 106. 
rios e, por isso mesmo, a maneira como imitam a natureza do nome ideal é mais evidente e tende a se aproximar da compreensão naturalista de Crátilo, uma vez que não poderia haver mudança nos elementos do nome sem que haja uma mudança proporcional em seu significado (posto que esses elementos já possuem significação própria). Revelando assim a força da posição naturalista, dado que a organização interna dos nomes derivados de fato tenderá sempre a refletir alguma concepção formal da coisa referenciada. Mais do que isso, essa organização poderá se repetir em outras linguas apenas utilizando-se dos nomes primários equivalentes, como quando dizemos televisão em português (o sufixo "tele" indica distância e "visão" o ato de ver) e fernsehen em alemão ("fern" significa distante e "sehen" é o infinitivo do verbo ver).

Fica, entretanto, patente que a verdadeira correção dos nomes derivados pressupõe de alguma forma a correção dos nomes primários, visto que aqueles dependem destes. Sócrates nota, ademais, que os nomes primários são compostos de sílabas e sons, logo sua imitação da forma do nome terá de ser feita através deles, um pouco como a música se utiliza de sons para sua imitação artística (423c-d). O filósofo procede a uma sistematização dos tipos de fonemas que podem compor um nome (424c-d), algo que, segundo percebe Ademollo, 55 influenciará posteriormente o Teeteto ${ }^{56}$ e mesmo a Poética aristotélica. ${ }^{57}$ Da separação dos fonemas, deve-se seguir a separação dos seres e a sua associação com os sons, tendo como base a semelhança que apresentem um com o outro (424d-425a). Procedimento que Sócrates, de forma um tanto sincera, julga ridiculo, porém necessário para que se continue a sustentar a correção dos nomes primários (425d), da qual depende toda a concepção do naturalismo absoluto de Crátilo. Até agora Sócrates vinha defendendo a tese do naturalismo absoluto, porém, conforme vimos acima, esta implicava, na perspectiva de Crátilo, que nomes que falhem em sua imitação (em qualquer grau que seja) não podem ser considerados absolutamente como nomes. Algo que culmina na crença da impossibilidade de se dizer o falso, pois admite o falso nome (entendido também como predicado). Contudo, para Platão essa tese é inaceitável e, por isso mesmo, Sócrates não poderia aderir a ela. Destarte, opõe-lhe a visão de que não apenas os nomes podem falhar em sua imitação, como também podem fazê-lo em grau maior ou menor, visto que um nome pode estar mais ou menos adequado a seu referente (429b). Esses indicios começam a revelar que a oposição que está se formando entre Sócrates e Crátilo é aquela entre a terceira e quarta classificação do "ser por natureza", tal qual afirmava Proclo, $5^{8}$ e é a partir daqui que a visão destes dois filósofos se distinguirá plenamente, revelando a real solução platônica para o problema da justificação dos nomes.

\section{A via socrática}

No ponto em que atingimos do diálogo já se havia chegado a um acordo mútuo entre os debatedores quanto ao fato de que (1) os nomes concernem de algum modo à natureza das coisas, (2) e que há um artesão especializado na arte da construção dos nomes. Será, contudo, necessário resolver um embaraço que se apresentou tanto na argumentação do naturalismo quanto do convencionalismo, nomeadamente a impossibilidade de dizer o falso. De fato, o diálogo parece encaminhar-nos à compreensão de que a justificação dos nomes não pode ser nem totalmente arbitrária de modo a excluir a verdade, porém não tão ajustada de modo a excluir o falso, devendo ser considerada como esta dupla potência do acerto e do erro, tendo, portanto, de explicar a passagem de um a outro por algum elemento que não ela mesma. Para tanto, todavia, falta ainda conseguir a concessão de que os nomes possam ser imitações tanto melhores quanto piores das coisas imitadas, algo

\footnotetext{
ADEMOLLO, op. cit., p. 284.

PLATÃO. Teeteto. In: Diálogos I. Tradução de Edson Bini. São Paulo: Edipro, 2007. 203b, p. 142

ARISTÓTELES. Poética, XX.1456b25-31.

PROCLO, op. cit., p. 73.
} 
que, conforme vimos, Crátilo negava totalmente. Sócrates nesse ponto evitará atacar o argumento de forma direta, dizendo-se incapaz de resolver a problemática da falsidade (429d-e), sustentada tão veementemente por seu adversário. Em verdade a questão só virá a ser totalmente apurada e sanada no diálogo Sofista e, de acordo com uma opinião bastante difundida entre comentadores, isto pode ter se devido ao fato de o próprio Platão ainda ter dificuldades, naquele momento, em refutar a falácia apresentada. ${ }^{59}$

Seja como for, Sócrates adota a estratégia de demonstrar a real proporção da visão que Crátilo está propondo, enfatizando que esse não está meramente negando a classificação de um fenômeno como sendo "dizer o falso", mas a própria possibilidade do erro e da falsidade. Assim, o primeiro argumento apresentado é o de que no âmbito da pintura possa haver boas e más representações (429a6-b2), e quanto a isso não haverá objeção uma vez que os dois admitem que a qualidade da pintura dependa largamente da habilidade do pintor. Isso poderia parecer implicar que tal também fosse o caso para todas as demais artes, porém Crátilo declara ser o nomear uma exceção, dado que ele não concebe que os verdadeiros nomeadores variem em suas habilidades de nomear. Mais do que isso, ele declara que nomes ruins (ou nomes mal atribuidos) não são nomes de maneira alguma (429b9-10), tal como já havíamos apontado anteriormente. Essas visões implicam, tal como nota Bagwell, ${ }^{60}$ em uma visão infalivel do normatizador. Crátilo não tem dificuldade, contudo, em admitir que os nomes sejam, ainda sim, algum tipo de imitação (430a9-b5). Sócrates terá, portanto, de encaminhar seu argumento por algum outro sentido.

Sócrates: Mas e se, outra vez, dirigindo-me a ele mesmo, eu dissesse "este é o seu nome"? Isso seria possivel na medida em que o nome é uma imitação como o retrato. Quero dizer, não seria o mesmo falar "este é o seu nome" e, através disso, instituir na percepção dos seus ouvidos uma imitação sua que, por acaso, diz que ele é um homem ou, ainda por acaso, ao usar um nome do gênero humano feminino, diz que ele é uma mulher? Na sua opinião, não pode ser gerado um tal exemplo?

Crátilo: Que seja, Sócrates! Meu desejo é de lhe consentir este ponto. ${ }^{61}$

Crátilo se vê compelido a aceitar o argumento, ainda que hesite em fazê-lo. Isso, porém, tal como imediatamente faz notar Sócrates (431a), implica no fim da disputa, posto que se é admitida a possibilidade da má distribuição dos nomes, então como não the atribuir também o nome de falsidade? Mais que isso, se os nomes podem ser mal distribuidos, então também os verbos ( o podem ser, "e se é possivel colocar os nomes e os verbos deste modo, é necessário que seja também no caso das falas ( $\lambda$ óyol), na medida em que as falas, eu acho, são compostas deles". ${ }^{62}$ Efetivamente, o que Platão está fazendo nessa passagem é identificar a falsidade do discurso com a atribuição equivocada de um nome a um verbo e, portanto, tirando a discussão do nível meramente nominal (isto é, onde apenas a veracidade do nome é considerada) para o nivel propriamente discursivo (onde a relação do nome com seu predicado passa a ter papel principal). Ademais, essa forma de compreender o discurso como sendo um composto de nomes e verbos será ainda posteriormente corroborada no Sofista (em 263d). Muitas das aporias do Crátilo encontrarão soluções nesse diálogo, incluindo, como já afirmamos, a da justificação da possibilidade de dizer o não ser, mas, principalmente, é nele que essa compreensão acerca da composição do discurso ganhará sua verdadeira proporção no estabelecimento claro da teoria das ideias. ${ }^{63}$ Acredito ser, entretanto, bastante evidente com base nos pontos apresentados acima, que os germes da compreensão da "communauté des genres", tal como analisado por Diès, 64 já estava presente em Platão ao escrever o Crátilo, e se

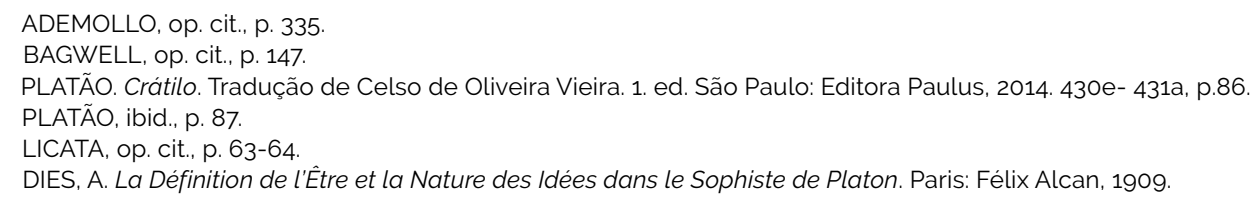


não o apresentou mais explicitamente podemos supor que ou ainda enfrentava dificuldades em refutar a falácia de Crátilo (tal como dissemos ser a posição de muitos) ou preferiu ater-se no diálogo à questão dos nomes deixando a da relação dos nomes entre si (princípio da predicação) para ser abordada posteriormente.

Voltando à analogia com a pintura, Sócrates tenta mais uma vez estipular a possibilidade que um nome, constituido de elementos de imitação, venha a ser mais adequado ou menos adequado à coisa imitada (431c-e). Encontra-se, porém, mais uma vez com a resistência por parte de Crátilo que objeta argumentando que se adiciona ou se subtrai alguma letra a um nome não se terá mais o nome correto e, de maneira geral, "sequer estará escrito, pois, após ter sofrido uma alteração, já é, simplesmente, outro" (431e). Méridier ${ }^{65}$ faz notar, nesse ponto, que essa defesa parece contradizer a aprovação que Crátilo deu às investigações etimológicas (em 428c), uma vez que havia suposto que etimologias se originam de adições, omissões e transposições de letras, em parte por conta da ação do tempo e dos falantes que gostam de embelezar os discursos (414C-d). Sócrates responde que não é característico de todas as coisas serem sempre compostas de um exato número de elementos e, em caso contrário, não se poder dizer que sejam de maneira alguma. Esse é, de fato, o caso dos números, posto que o dez deverá ser divisivel em dez unidades e caso the sejam subtraídos ou adicionados outros elementos não mais se poderá dizer que seja dez. Contudo, as outras formas de imitação, como pintura e mesmo o nomear, não se dão dessa forma, o que evidencia o contraste entre as duas compreensões de nome segundo a natureza que, tal como vimos, já anunciara Proclo: ${ }^{66}$ primeiro uma compreensão que se baseia em uma imagem necessariamente ajustada tal como o reflexo de um homem ou sua sombra; ao que se opõe a visão que Sócrates apresenta de uma imitação artificial da natureza da coisa nomeada tal como se vê nas artes da escultura e da pintura.

Para prosseguir na discussão, Sócrates deixa claro que os nomes não podemestar tão ajustados de modo a deixarem de ser imitações, ainda que sejam de origem divina, uma vez que essas devem sempre distinguir-se da coisa imitada e, portanto, conter alguma imperfeição. Aqui seria interessante notar com Bagwell ${ }^{67}$ que se todos os nomes fossem de fato iguais quanto à origem e adequação, podendo apenas haver nomes naturalmente ajustados e não nomes naturalmente desajustados, isto implicaria em não haver a necessidade da supervisão do dialético. De fato, não é a primeira vez que Platão atribui ao usuário de dado instrumento a justiça de julgar o trabalho do artesão (República 601d). No caso das artes isso se dá porque o usuário detém a correta opinião sobre o uso do instrumento e, assim, deve ensinar o artesão quanto ao que funciona melhor e pior. No caso da língua, entretanto, o dialético não deve ter apenas opinião correta, pois isso o reduziria imediatamente ao nível do retórico (que visa apenas a uma finalidade técnica objetiva: o convencimento), mas, ao contrário, deve deter ciência da natureza da coisa nomeada. Isto, contudo, será contradito pela visão que Crátilo apresentará logo na sequência ao afirmar que "quem tem a consciência dos nomes também vai ter a consciência das coisas". ${ }^{6}$

Esta obstinação de Crátilo em negar que o normatizador possa errar expor-lhe-á à contradição de que, apesar de asseverar o constante fluxo de tudo, nega que os nomes e aqueles que os cunham mudem da mesma forma, algo que revela um pouco da fina ironia com que Platão constrói seus diálogos. ${ }^{69}$ Ele passa, portanto, a apostar na consistência da visão de mundo que os normatizadores imprimiram nos nomes (436b-c). A isso, contudo, Sócrates antepõe o exemplo do geômetra que em seu raciocínio admite uma premissa errada (436d). Ao proceder em sua demonstração esse geômetra

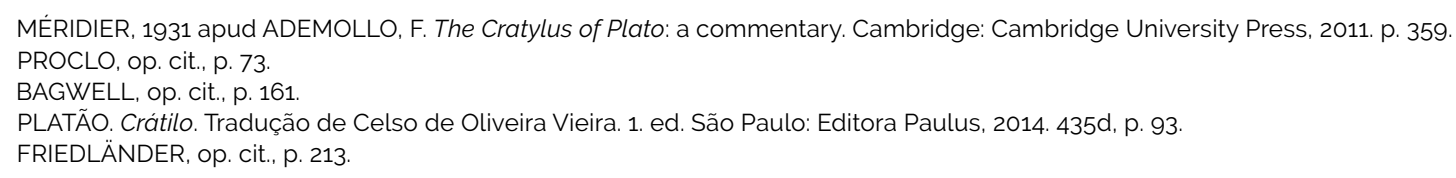


cometerá erros que são atribuiveis a essa primeira admissão, ainda que em um primeiro momento toda a lógica do argumento pareça perfeitamente consistente consigo mesma. Do mesmo modo, poder-se-ia supor que o normatizador tivesse admitido na construção original dos nomes visões que não correspondem à realidade mesma das coisas. Nesse ponto, Sócrates começa a examinar

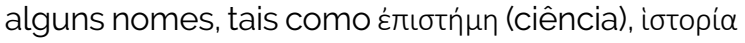
(investigação) e $\mu v$ ń (memória), visando pôr à prova a consistência da visão do normatizador endossada por Crátilo.

Sócrates: Vamos averiguar se é assim mesmo tomando, primeiro, o próprio nome ciência. Como ele é ambíguo! Parece mais sinalizar a continência da nossa alma diante das coisas em vez de garantir estarmos cientes do seu movimento. Assim, seria mais correto falar como agora do que inserir um " $\mathrm{t}$ " no final como em "scientia". Na sequência, tem o estável, que é imitação do estar de algo e não do seu movimento. Também a história indica a estabilidade de uma coisa provisória. A confiança indica que há de fiar no confinado. Assim como a memória é o que está metido de forma peremptória na alma, e não em movimento. ${ }^{70}$

Nessas breves considerações etimológicas de Sócrates já podemos ver cair por terra o argumento de uma consistência na construção dos nomes que seria indicativa da realidade constantemente em fluxo. Crátilo, em desespero, ainda tentará recorrer ao argumento de que "a maioria assinala movimento",71 o que é inútil, uma vez que seria inadmissivel para uma visão divina do normatizador aceitar que esse acerte em suas imposições apenas na maioria das vezes. Nisso já podemos observar o que levou Sócrates a considerar a necessidade da convenção para a justificação de pelo menos alguns dos nomes (em 435c). Assim, aparentemente, nem o naturalismo é descartado, nem o convencionalismo é abraçado totalmente na visão platônica. Alcino em sua Exposição das Doutrinas de Platão explica essa posição da seguinte forma: "a justeza dos nomes é questão de convenção, isto, porém, não de forma absoluta, nem de outra qualquer, mas de maneira que a imposição do nome siga a natureza da coisa".72 Nesse sentido, nem a convenção arbitrária nem a ação da natureza dão conta da verdadeira compreensão do nome, mas uma junção das duas coisas que se expressa na adequação do discurso à natureza das coisas nomeadas. Ademais, na interpretação de Proclo ${ }^{73}$ somos levados a considerar que os nomes que dizem respeito às realidades mutáveis devem depender em maior grau da convenção como um "meio vulgar de justificação" (435c), enquanto os nomes das realidades imutáveis devem depender mais da imitação direta. Ademollo, ${ }^{74}$ contudo, argumenta contra essas interpretações conciliatórias apresentando a Carta VII como evidência de que Platão acreditava realmente que os nomes deviam sua justificação tão somente à convenção, e apenas admitiu que Sócrates sustentasse no diálogo uma visão que não descarta de todo o naturalismo como um artificio para garantir que Crátilo se mantivesse investido na discussão.

De fato, na Carta VII Platão afirma claramente que não há "razão alguma que nos impeça de chamar aquilo que chamamos agora de redondo, de reto, e este de redondo"75, algo que parece ir inteiramente a contramão de algumas afirmações do Crátilo, principalmente em 433.e-434.a. Essas considerações levaram alguns autores a duvidar da autoria da carta, tendo Sedley ${ }^{76}$ decidido por desconsiderá-la de todo em sua análise, apresentando o argumento de que, no diálogo, a concessão que Sócrates fez ao convencionalismo foi mínima e aplicava-se somente a palavras que continham o mesmo número de sons apropriados e inapropriados a sua natureza. Como, porém, devemos nós proceder quanto a esses problemas? A autoria das cartas atribuidas a Platão é uma discussão em si mesma e não faz parte do escopo de nossa pesquisa. Não obstante,

\footnotetext{
PLATÃo. Crátilo. Tradução de Celso de Oliveira Vieira. 1. ed. São Paulo: Editora Paulus, 2014. 437a-437b, p. 95, grifo nosso. Ibid., p. 96.

ALCINO. Enseignement des doctrines de Platon. Paris: Les Belles Lettres, 1990. p. 14.

PROCLO. Lecturas del Crátilo de Platón. Madrid: Ediciones Akal, 1999. p. 69

ADEMOLLO, op. cit., p. 413-424.

PLATÃO. Carta VII. In: PLATÃo. Cartas e Epigramas. Tradução de Edson Bini. São Paulo: Edipro, 2012. 343b, p. 88

SEDLEY, D. Plato on Language. In: BENSON, H. (ed.). A Companion to Plato. Oxford: Blackwell Publishing, 2006. p. 220.
} 
ainda que concedamos, pela força do argumento, a dúvida quanto à validade de seus conteúdos, seria dificil ignorar as outras passagens do corpus platônico que também apontam para um convencionalismo, como na República 533.e. Sofista 227.b-c e no Politico 261.e. Extrapolar disto para a crença em um completo convencionalismo Socrático, como faz Ademollo, ${ }^{77}$ seria perder de vista toda a argumentação inicial do diálogo por onde concluimos que a total arbitrariedade do signo linguístico, implicada em um fechamento para a natureza mesma da coisa nomeada, acabaria por cair em uma espécie de anarquismo referencial e na impossibilidade de dizer o falso. Ademais, esse movimento circular que está implicado na crença do retorno ao convencionalismo não nos parece nada satisfatório para lidar com o movimento de ascensão às coisas mesmas que haviamos identificado por baixo da discussão sobre os nomes.

Com efeito, a possibilidade do discurso está implicada em uma abertura para a realidade das formas, tal como Platão faz notar expressamente no Parmênides em 135.b-c. Neste trecho, O personagem de Parmênides instrui um Sócrates ainda jovem de que aquele que nega por completo a realidade das formas teria de negar também que haja uma identidade nas coisas que as mantém sendo elas mesmas, e que sem esse pressuposto o discurso é simplesmente impossivel. Ora, essa abertura ao campo do inteligivel que está presente na fala não poderia ser ela mesma matéria de convenção em hipótese alguma, uma vez que submeteria uma realidade divina (as ideias) a uma realidade humana (a convenção), mas também não poderia ser de tal forma que viesse a determinar a linguagem totalmente, chegando-se à negação da possibilidade mesma do erro. Nesse sentido, a interpretação que fazem Proclo e Alcino aparenta condizer muito bem com o desenvolvimento da posição Socrática tal como analisamos, posto que admite um concurso entre natureza e convenção que se exprime na atividade mesma do dizer, ${ }^{78}$ tendo sua garantia final referida à figura do dialético. Aqui caberia perfeitamente a distinção que Proclo79 faz entre o aspecto material e o imaterial (ou formal) dos nomes, isto é, entre à voz constituída nos fonemas (que são a matéria do nome) e os significados inteligiveis. Diz ele que, para Sócrates, os nomes necessariamente contêm esses dois aspectos e, assim, segundo a sua forma serão por natureza e segundo a matéria serão por convenção, devendo ser compreendidos como "vestígios de um pensamento conhecedor"80 e não como um simples impulso natural. Além disso, vemo-lo referir a forma dos nomes exatamente àquela realidade identitária que vimos ser afirmada por Platão no Parmênides.

Ademollo, ${ }^{81}$ porém, critica essa posição alegando que, na interpretação de Proclo (também na de Amônio), Sócrates estaria realizando uma distinção entre nomes que são justificados por mera convenção e nomes que são justificados somente por natureza, sendo esses últimos os referentes às coisas eternas. Disso, tal como ele nota, seguir-se-iam várias complicações interpretativas do diálogo. Cremos, contudo, que essa crítica seja infundada visto que Proclo ${ }^{82}$ deixa claro em seu comentário que todos os nomes devem ser entendidos como tomando parte da natureza e parte da convenção, ainda que os que se referem aos entes imóveis possam ser entendidos como estando mais ligados à natureza, mas não de forma exclusiva. Contudo, para além de ajudar-nos a superar a dificuldade da oscilação entre naturalismo e convencionalismo nos testemunhos de Platão, essa concepção da dupla realidade do nome encontra um possivel reforço em uma passagem do diálogo Timeu. De fato, em 37 b ouvimos de Platão que a expressão ou

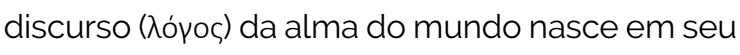
interior na ausência de som ou de voz (äveu фĐópyou kai ńxñc). Isto é, completamente afastada daquilo que para o discurso representa a sua matéria, se-

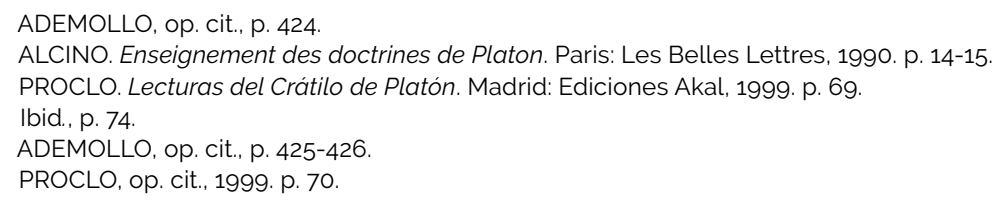


gundo identificado por Proclo. Sendo assim, não seria possivel relacionar esta expressão imaterial do logos na alma do mundo com a geração das "ideias dos nomes", tal como no Crátilo vemos ser atribuído ao onomaturgo (389.d-e)? De fato, tal como víramos anteriormente. Proclo chegou a afirmar a identidade entre o demiurgo do Timeu e do normatizador divino do Crátilo. Algo corroborado, ademais, pela afirmação de Reale ${ }^{83} \mathrm{em}$ seu livro de que as ideias dos artefatos são realmente de origem demiúrgica, estando entre esses - por que não? - o próprio nome entendido como instrumento de distinção (388.b). Se compreendida dessa forma, a solução platônica da problemática da justificação dos nomes nos parece muito mais coerente com o desenvolvimento total do movimento do diálogo. Restariam outros problemas a resolver que necessitariam de pesquisas próprias, mas para nós basta aqui a observação de que a interpretação dos antigos comentadores quanto a essa posição não só não se afigura como absurda, no que discordamos de Ademollo, como poderia até nos ajudar a sanar algumas passagens obscuras e dificultosas de outros diálogos.

\section{Considerações finais}

Este artigo teve como objetivo contrapor-se à visão de que Sócrates, ao final da obra, tome partido do convencionalismo, posição defendida, conforme visto, por Ademollo, ou mesmo que retorne a um naturalismo tal como argumentou Sedley. De início discutiu-se a posição de Hermógenes que, conforme vimos, alinhava-se com um tipo de relativismo dos nomes, dado que ele atribuia sua justificação àquilo que nomeamos uma "imposição". Contra isso, Sócrates busca remeter à compreensão do nomear como uma arte que, por consequência, não pode se orientar por uma mera arbitrariedade do sujeito, devendo sim envolver alguma técnica e que implicaria em um artesão apropriado. A essa figura do artesão dos nomes foi atribuido o título de "normatizador" (389a) e é logo associado com algum aspecto do divino, pois seria o responsável por dar verdade aos nomes. Disso cai-se quase que inevitavelmente na visão de um naturalismo, onde os nomes, sendo divinamente ajustados, contêm neles mesmos já toda a verdade do discurso, exatamente como supunha Crátilo. Isso, contudo, termina por implicar na impossibilidade de dizer o falso, algo que, conforme visto, é inaceitável se se quer admitir a possibilidade da investigação filosófica e do conhecimento enquanto tal. Assim, sustentamos a interpretação de que a resposta platônica para o problema dos nomes só pode se dar em uma terceira via que, aceitando a deficiência da realidade material dos nomes, atribui a justificação e possibilidade do conhecimento dialético na realidade formal ou ideal dos nomes, tal como averiguamos presente no Timeu.

\section{Referências}

ACKRILL, J. L. Language and Reality in Plato's Cratylus. In: Essays on Plato and Aristotle. Oxford: Oxford University Press, 1997, p. 33-52.

ADEMOLLO, F. The Cratylus of Plato: a commentary. Cambridge: Cambridge University Press, 2011.

ALCINO. Enseignement des doctrines de Platon. Paris: Les Belles Lettres, 1990.

AQUINO, T. de. Comentário ao Sobre a Interpretação de Aristóteles. Campinas: Vide Editorial, 2018.

ARISTÓTELES. Metafísica. Tradução de Marcelo Perine. São Paulo: Edições Loyola, 2015. v. II.

ARISTÓTELES. Poética. Tradução de Paulo Pinheiro. São Paulo: Editora 34, 2015

BAGWELL, G. S. A Study of Plato's Cratylus. 2010. Tese [Doutorado em Filosofia] - Duquesne University, Pittsburgh, 2010. Disponivel em: https://dsc.duq.edu/etd. Acesso em: 2 jan. 2019.

DEMOS, R. Plato's Philosophy of Language. The Journal of Philosophy, [S. I.], v. 61, n. 20, p. 595-610,1964.

DIELS, H.; KRANZ, W. Die Fragmente der Vorsokratiker. Zürich: Weidmann, 1996.

DIES, A. La Définition de l'Être et la Nature des Idées dans le Sophiste de Platon. Paris: Félix Alcan, 1909.

FRIEDLÄNDER, P. Plato: The Dialogues, First Period. Translation by Hans Meyerhoff. New York: Pantheon Books, 1964. v. 2. 
LICATA, G. Teoria dei nomi e teoria ele idee in Platone. Dialegesthai. Rivista Telemática di filosofia, Roma, ano 3, 2002. Disponivel em: http://mondodomani.org/dialegesthai/gl01.htm. Acesso em: 18 nov. 2018.

PLATÃo. A República. Tradução de Pietro Nassetti. São Paulo: Martin Claret, 2009

PLATÃo. Cartas e Epigramas. Tradução de Edson Bini. São Paulo: Edipro, 2012.

PLATÃO. Crátilo. Tradução de Celso de Oliveira Vieira. 1. ed. São Paulo: Paulus, 2014.

PLATÃo. Diálogos I. Tradução de Edson Bini. São Paulo: Edipro, 2007.

PLATÃo. Diálogos IV. Tradução de Edson Bini. São Paulo: Edipro, 2015

PLATÃO. Diálogos V. Tradução de Edson Bini. São Paulo: Edipro, 2010

PROCLO. Lecturas del Crátilo de Platón. Madrid: Ediciones Akal, 1999

REALE, G. Para uma Nova Interpretação de Platão. 2. ed. São Paulo: Edições Loyola, 2004.

SEDLEY, D. Plato's Cratylus. Cambridge: Cambridge University Press, 2003.

SEDLEY, D. Plato on Language. In: BENSON, H. (ed.). A Companion to Plato. Oxford: Blackwell Publishing, 2006. p. 214-227.

VAZ, H. C. de L. Contemplação e dialética nos diálogos platônicos. São Paulo: Edições Loyola, 2012.

XENOFONTE. Ditos e Feitos Memoráveis de Sócrates. São Paulo: Nova Cultura, 1999.

\section{Cássio Mercier Ramos}

Mestre em Filosofia pela Pontificia Universidade Católica de São Paulo (PUC-SP), em São Paulo, SP, Brasil.

\section{Endereço para correspondência}

Cássio Mercier Ramos

Rua engenheiro Elias Machado de Almeida, 136

Caxingui, 05517-070

São Paulo, SP, Brasil

Os textos deste artigo foram revisados pela Poá Comunicação e submetidos para validação do autor antes da publicação. 